\title{
Z DALEKIEGO WSCHODU NA BLISKI WSCHÓD, DO AFRYKI PÓLNOCNEJ I EUROPY. POLACY Z MANDŻURII W SZEREGACH WOJSKA POLSKIEGO W LATACH 1939-1945*
}

Kiedy na przełomie XIX i XX wieku w Mandżurii zaczęli osiedlać się Polacy², ich ojczyzna znajdowała się od ponad stu lat pod zaborem rosyjskim, pruskim i austriackim. Nad Amur lub Morze Żółte trafiali głównie Polacy z zaboru rosyjskiego, jednak nie kierowały nimi żadne pobudki imperialistyczne, lecz najczęściej chęć poprawy swojej sytuacji materialnej czy też służba w armii carskiej, do której byli wcielani². Pomimo wielu lat życia w niewoli, naród polski nie wyrzekł się chęci

Mgr Mariusz Borysiewicz - doktorant, Instytut Historii i Politologii na Wydziale Filologiczno-Historycznym Akademii Pomorskiej w Słupsku; email: mariuszbory@wp.pl

* Niniejszy artykuł stanowi I część pracy o Polonii mandżurskiej; II część ukaże się w dalszych tomach „Studiów Polonijnych”.

1 Zbiory prywatne Leonarda Spychalskiego, rękopis „Mój Harbin” (brak daty), s. 1-2.

2 Archiwum Archidiecezjalne w Gnieźnie [dalej: AAG], Archiwum Prymasa Polski [dalej: APP], sygn. 65, List s. Marii Immaculaty Łabujewskiej do prymasa Polski Augusta Hlonda z 14 grudnia 1928 r., k. 30. Z inicjatywy lokalnego proboszcza ks. Władysława Ostrowskiego w 1928 r. przybyły do Harbina siostry urszulanki, które zajęły się kształceniem i wychowaniem dziewcząt polskich i rosyjskich. Jednak w 1933 r. polsko-chińska misja sióstr urszulanek przeniosła się do wsi Tong-Hao na przedmieściach Harbina, gdzie do 1937 r. prowadziły dom dziecka i trzyklasową szkołę dla dziewcząt chińskich. Instytucja ta przyjęła nazwę St Ursula's College for Girls, a oprócz Chinek, uczyły się tam również Rosjanki i Polki. Z kolei w ochronce dla dziewcząt przebywało co najmniej 80 dzieci polskich, w tym wiele sierot. W czasie swojego pobytu w Mandżurii urszulanki zmagały się z licznymi problemami finansowymi i administracyjnymi. Na czele zgromadzenia stała s. Maria Immaculata Łabujewska, dzięki której misja utrzymała się na terenie stałych walk pomiędzy Chińczykami a Japończykami. Jej ofiarna praca spowodowała, że polskie urszulanki w Harbinie przetrwały oblężenie miasta przez wojska japońskie w 1932 r., następnie miesiące niepewności czy wybuchnie wojna między Japonią a ZSRR, katastrofalną powódź i epidemię dżumy. W 1946 r. siostry zostały zmuszone do opuszczenia swojej dotychczasowej siedziby. Wobec nasilających się represji ze strony władz chińskich urszulanki zdecydowały się na powrót do kraju w organizowanej latem 1949 r. akcji reemigracyjnej mandżurskiej Polonii. Misjonarki wyjechały z Harbina 3 lipca 1949 r. w pierwszym transporcie reemigrantów. Po przybyciu do kraju udały się do klasztoru w Krakowie (Polski list z Dalekiego Wschodu, „Dziennik Łódzki” 1931, nr 87, s. 3; Polsko-chińska misja ss. urszulanek, „Gazeta Polska” 
walki o odzyskanie niepodległości ${ }^{3}$. Myśl o wolnej Polsce i powrocie do niej nie opuszczała także Polaków w Mandżurii. Świadczy o tym fakt, że gdy pod koniec 1918 r. Polska odzyskała suwerenność, zdecydowana większość naszych rodaków osiadłych w Mandżurii i Chinach wróciła do ojczyzny ${ }^{4}$. Natomiast ci, którzy pozostali na Dalekim Wschodzie, utrzymywali ożywione kontakty z odległą ojczyzną, a także manifestowali lojalną postawę obywatelską wobec odrodzonej państwowości polskiej ${ }^{5}$.

Życie dalekowschodniej Polonii skupiało się w tamtym czasie przede wszystkim w Harbinie, a więc głównym ośrodku miejskim północnej Mandżurii i jednocześnie stolicy dawnej eksterytorialnej strefy Kolei Wschodniochińskiej ${ }^{6}$. Zorganizowaną działalność wychodźstwa polskiego animowały przeważnie trzy instytucje, to znaczy Kościół katolicki ${ }^{7}$, świeckie stowarzyszenie społeczno-kulturalne „Gospoda

1933, nr 37, s. 2; C. SejBuk, Polskie Siostry Urszulanki w Harbinie, „Misje Katolickie” 1938, nr 57, s. 323-325; A. Judycka, Z. Judycki, Duchowieństwo polskie w świecie, Toruń 2002, s. 215-216).

${ }^{3}$ Pierwszą polską organizacją niepodległościową w północnowschodnich Chinach był Związek Polaków Wojskowych w Mandżurii, założony w 1917 r. w rezultacie Ogólnego Zjazdu Polaków Wojskowych w Harbinie, który odbywał się od 14 do 27 maja 1917 r. Podobne związki zakładano także w innych rosyjskich miastach, a Zarząd Centralny mieścił się w Petersburgu (ówczesnym Piotrogrodzie). Organizacja ta skupiała głównie Polaków służących w armii rosyjskiej, jednak mogli do niej należeć również cywile. Celem Związku była odbudowa niepodległej Polski. Teren działań obejmował Harbin i mniejsze posterunki wojskowe w Mandżurii. Najważniejsze zadania sprowadzały się do prowadzenia spisu polskich żołnierzy mieszkających w Mandżurii i utrwalania tożsamości narodowej poprzez urządzanie odczytów, kursów naukowych oraz szerzenie czytelnictwa. Związek ten przestał istnieć po demobilizacji armii carskiej w początkach $1918 \mathrm{r}$. Jego miejsce zajęła Polska Rada Polityczna Dalekiego Wschodu (Archiwum Akt Nowych [dalej: AAN], Kolonia Polska w Mandżurii [dalej: KPM], sygn. 1, Uchwały Pierwszego Ogólnego Zjazdu Wojskowych Polaków, Piotrogród, 6 czerwca 1917 r., k. 11-12; AAN, KPM, sygn. 1, Ustawa Związku Polaków Wojskowych w Mandżurii z 27 maja 1917 r., k. 1-2; K. Symonolewicz, Miraże mandżurskie, Warszawa 1932, s. 254).

${ }^{4}$ R. SŁAwiŃski, The Modern History of China, Kraków 2006, s. 117.

5 J. Neja, Polacy w Mandżurii, „Biuletyn Instytutu Pamięci Narodowej” 2002, nr 3, s. 34.

${ }^{6}$ AAG, APP, sygn. 4, Sprawozdanie Rady Organizacyjnej Polaków z Zagranicy z 1 listopada 1932 r., k. 49.

${ }^{7}$ Pierwsi Polacy, którzy przybyli do Mandżurii w 1897 r., początkowo korzystali z duszpasterskiej posługi kapłanów francuskich, pracujących wśród tamtejszych plemion już od końca XV stulecia (M. Wojciechowicz, Placówka wschodnia w Harbinie, [w:] Marianie 1673-1973, red. J. Bukowicz, T. Górski, Rzym 1975, s. 244-268; J. TyCZKA, Na wschodzie i na zachodzie, Warszawa 2003, s. $77-$ 85). W 1901 r. na przedmieściu Harbina otworzono kaplicę dla Polaków, która mieściła się w budynku będącym własnością Korpusu Straży Pogranicznej. Wówczas msze święte i obowiązki duszpasterskie sprawował kapelan wojskowy ks. Adam Szpiganowicz. Rok później rozpoczął on starania o miejsce na budowę kościoła (Historia parafii polsko-katolickiej w Charbinie, „Pamiętnik Charbiński” 1923, cz. 1, s. 23). W 1904 r. jego miejsce zajął dojeżdżający z Władywostoku ks. Stanisław Ławrynowicz, 


\section{Polska" oraz Konsulat Rzeczypospolitej Polskiej9, który od 1939 r. funkcjonował jako Konsulat Generalny RP ${ }^{11}$. Co więcej, przy „Gospodzie Polskiej” jako autono-}

zastąpiony z kolei przez ks. Antoniego Maczuka w 1907 r. (M. CzermiŃski, Z opowiadań Władysława Ostrowskiego, „Misje Katolickie” 1912, nr 31, s. 285). Już w 1906 r. rozpoczęto budowę kościoła pod wezwaniem św. Stanisława. Poświęcenia nowej świątyni dokonał 1 sierpnia 1909 r. ks. bp Jan Cieplak odbywający wizytację na Syberii. Kościół szybko stał się jednym z najważniejszych ośrodków życia polskiego w Mandżurii, przyciągając wielu ludzi, zwłaszcza takich, którzy nie angażowali się w inne sprawy polskiej diaspory. Nowa parafia należała do diecezji mohylewskiej, a na jej terenie mieszkali nie tylko Polacy, lecz również nieliczni Niemcy, Irlandczycy i Litwini (K. Grochowski, Polacy na Dalekim Wschodzie, Harbin 1928, s. 18-19). W 1924 r. wydzielono z parafii św. Stanisława fragment miasta (tzw. Przystań) i utworzono tam nową parafię św. Jozafata. Dołączono do niej również wszystkie osady leżące wzdłuż zachodniej części linii Kolei Wschodniochińskiej. Proboszczem został ks. Antoni Leszczewicz. Poświęcenie kościoła nastąpiło w 1925 r., a później utworzono w nim szkółkę początkową. W 1945 r., gdy zlikwidowano polskie organizacje, Kościół był jednym z niewielu ośrodków, przy których skupiali się Polacy. Wraz z wyjazdem prawie wszystkich przedstawicieli polskiej kolonii w 1949 r., wyjechali również polscy księża. Kościoły i pozostały majątek obu parafii trafił w ręce chińskich komunistów (Archiwum Towarzystwa Chrystusowego, Liber baptizatorum 1906-1909, sygn. DR/XIV/1/1, księgi metrykalne z lat 1906-1909, s. 2-10; A. JABŁOŃSKA, K. KRĄKowski, Z dziejów Polonii Harbińskiej, „Przegląd Orientalistyczny” 1961, nr 2(38), s. 171; E. KAJDAŃSKI, Korytarz. Burzliwe dzieje Kolei Wschodniochińskiej 1898-1998, Warszawa 2000, s. 172-176).

${ }^{8}$ Stowarzyszenie „Gospoda Polska” w latach 1907-1949 prowadziło szeroką działalność kulturalną, edukacyjną i dobroczynną. Ta pierwsza świecka organizacja Polaków w Harbinie powstała z inicjatywy 35 osób w połowie 1907 r. Jako pierwszy funkcję prezesa pełnił Wiktor Roman. Siedziba stowarzyszenia znajdowała się początkowo $\mathrm{w}$ dwóch pomieszczeniach na plebanii przy kościele św. Stanisława. Jednak w grudniu 1907 r. podjęto decyzję o budowie własnego gmachu. Budowa - finansowana z kredytów, które miały być spłacone przez bogatszych przedstawicieli Polonii w zamian za udziały - ruszyła w 1912 r. W 1913 r. zbudowano jednopiętrowy gmach. Rok później dobudowano do niego salę ze sceną, a w 1919 r. drugie piętro. Stowarzyszenie, oprócz inicjatyw kulturalno-oświatowych, prowadziło działalność gastronomią i rozrywkową („Praca. Pismo Postępowe i Demokratyczne” 1918, nr 8, s. 10; S. NernheJM, Polonia harbińska (zarys historyczny), „Daleki Wschód” 1934, $\mathrm{nr} 7$, s. 2-3). Stowarzyszenie wykształciło też specyficzny sposób rozstrzygania sporów pomiędzy członkami „Gospody Polskiej” przy pomocy Sądu Obywatelskiego i Sądu Honorowego. Jednak wyroki tych instytucji dotyczyły głównie spraw, które nie wzbudzały większych kontrowersji (Stowarzyszenia polskie w Charbinie, Chiny, „Pamiętnik Charbiński” 1923, cz. 1, s. 18; AAN, KPM, sygn. 28 , Stowarzyszenie „Gospoda Polska” w Harbinie, k. 5-8).

${ }^{9}$ Polski konsulat w Harbinie utworzono w celu zabezpieczenia praw lokalnej Polonii, przeważnie składającej się z urzędników, pracowników Kolei Wschodniochińskiej oraz wpływowych przedsiębiorców (Centralne Archiwum Wojskowe [dalej: CAW], Oddział II Sztabu Głównego (Generalnego) z lat 1921-1939 [dalej: OIISG], sygn. I.303.4.4332, Sprawozdanie z podróży po Mandżurii ppłk. Wacława Jędrzejewicza z 30 września 1925 r., k. 8). Początkowo placówka działała bez zawarcia umowy polsko-chińskiej oraz bez formalnej aprobaty miejscowych władz chińskich, które ulegały ciągłym zmianom personalnym i kompetencyjnym (Instytut Polski i Muzeum im. gen. Sikorskiego [dalej: IPMS], Ambasada RP przy Stolicy Apostolskiej [dalej: ARP], sygn. A.44.122/2, Raport Delegacji RP w Charbinie z 17 czerwca 1929 r., k. 210). Kilkakrotnie zmieniano jej nazwę, przez co 
miczne sekcje rozwinęły działalność rozmaite pomniejsze organizacje i koła. Warto wspomnieć m.in. o Związku Młodzieży Polskiej ${ }^{11}$, Polskim Związku Automobilistów, Związku Pracowników Kolejowych ${ }^{12}$, Kole Miłośników Sceny Polskiej ${ }^{13}$, Polskim Towarzystwie Dobroczynności i licznych drużynach sportowych ${ }^{15}$.

określano ją jako konsulat (1920-1924), delegację RP (1924-1939), konsulat generalny (1939-1941), a także kompetencje, zarówno terytorialne, jak i urzędnicze. Urząd ten zajmował się sprawami z całego Dalekiego Wschodu, chociaż formalnym obszarem jego działania była Mandżuria, a później państwo Mandżukuo. Placówka podlegała Poselstwu RP w Tokio, następnie Poselstwu w Szanghaju, czy też w różnych okresach bezpośrednio Ministerstwu Spraw Zagranicznych. Kolejni kierownicy urzędu mieli decydujący wpływ na kształt i rozwój mandżurskiej Polonii (Instytut Józefa Piłsudskiego w Ameryce, Adiutantura Generalna Naczelnego Wodza, sygn. 701/2/105, Raport Naczelnego Dowództwa WP w Warszawie z 10 listopada 1919 r., k. 298-301; W. SkóRA, Stużba konsularna Drugiej Rzeczypospolitej. Organizacja, kadry i działalność, Toruń 2006, s. 884; TENŻe, Organizacja i pierwszy okres działalności polskich konsulatów w Harbinie $i$ Władywostoku w latach 1920-1924, [w:] Polskie ślady na Dalekim Wschodzie. Polacy w Harbinie, red. A. Furier, Szczecin 2008, s. 78-90; TENŻE, Placówki MSZ Drugiej Rzeczypospolitej w Harbinie w latach 1920-1941 na tle dziejów Chin i Mandżurii (Mandżukuo). Szkic do problemu, [w:] Na szlakach dwóch światów. Studia ofiarowane Profesorowi Jerzemu Hauzińskiemu w 45-lecie pracy naukowej i dydaktycznej, red. A. Teterycz-Puzio, Słupsk 2016, s. 684-700).

10 Polska Stużba Zagraniczna po 1 września 1939 roku, Londyn 1954, s. 59.

11 Organizacja ta została założona 11 grudnia 1921 r. jako Koło Młodzieży Polskiej. W 1924 r. zjednoczyła się z „Gospodą Polską”. W tamtym czasie założono sekcję sportową, która stanowiła magnes dla wielu utalentowanych młodych ludzi. Kolejno powstały polskie drużyny sportowe, a więc hokejowa, koszykówki i piłki nożnej. Odnosiły one wymierne sukcesy w Mandżurii, a nawet wyjeżdżały do Japonii, Korei i na południe Chin. W połowie lat trzydziestych XX wieku Związek Młodzieży Polskiej w Harbinie liczył 117 osób. Pomimo braku szczegółowych wiadomości o jego działaniach w czasie II wojny światowej, można stwierdzić, iż przetrwał on aż do końca obecności dostrzegalnej społeczności polskiej w Mandżurii („Daleki Wschód” 1934, nr 7, s. 15-16; B.Z. WoJAS, Dzieje Polonii Charbińskiej, „Zeszyty Historyczne” 30(1974), s. 6-7).

12 Działalność tego związku stawała się coraz mniej widoczna wraz z wyjazdami polskich pracowników Kolei Wschodniochińskiej do Polski lub innych regionów Chin, które nie ustały pomimo groźby utraty emerytury po opuszczeniu Mandżurii (M. ŚwIDERSKI, Uwaga kolejarze, „Listy Harbińskie” 1932, nr 14, s. 8). Zdecydowana większość polskich kolejarzy opuściła Mandżurię w 1935 r., kiedy Japończykom udało się przejąć całkowitą kontrolę nad Koleją Wschodniochińską, a w konsekwencji nad całą gospodarką północno-wschodnich Chin (AAN, Ministerstwo Spraw Zagranicznych [dalej: MSZ], sygn. 5413, Chiny. Stosunki ekonomiczne z Polską, głównie handlowe, k. 3-4).

${ }^{13}$ Koło Miłośników Sceny Polskiej, działające jako teatr amatorski, miało do dyspozycji dużą salę teatralną w budynku „Gospody Polskiej”. Główne role odgrywali w nim Stanisława Hajwos (żona wieloletniego prezesa wspomnianego stowarzyszenia) i Tadeusz Szukiewicz, który przez pewien czas prowadził ten teatr. Koło kierowane przez niego stało na wysokim poziomie i budziło duże zainteresowanie w szeregach polskiej społeczności. Szukiewicz wraz z innymi członkami koła nie wahał się nawet wystąpić z rewią muzyczną (K. Symonolewicz-Symmons, Polonia w Charbinie, „Przegląd Polonijny” 1978, z. 2, s.107-111). Ten swoisty teatr „Gospody Polskiej” rozpoczął swoją 
Obecność Polonii w Mandżurii wiązała się z budową Kolei Wschodniochińskiej, łączącej Syberię z północnymi Chinami ${ }^{15}$, która przyciągała tysiące osób z najdalszych krańców Imperium Rosyjskiego w okolice słabo rozpoznanego pogranicza Rosji, Mongolii i Mandżurii ${ }^{16}$. Jej budowa miała miejsce w latach 1897-1903, a po ukończeniu liczyła ponad 2 tys. kilometrów. Polacy znaleźli się w pierwszej ekspedycji technicznej wysłanej przez rząd carski z Władywostoku dla wytyczenia linii Kolei Wschodniochińskiej. Grupa, kierowana przez inż. Adama Szydłowskiego, wyznaczyła 11 kwietnia 1898 r. miejsce na założenie centrum logistycznego nowej linii kolejowej ${ }^{17}$. Tak powstał dzisiejszy, liczący $10 \mathrm{mln}$ mieszkańców Harbin $^{18}$, który z biegiem lat stał się głównym ośrodkiem polskiej diaspory na Dalekim Wschodzie. $Z$ tego miasta Polacy rozprzestrzenili się na inne tereny Chin, a część $\mathrm{z}$ nich osiedliła się nawet w Australiii ${ }^{19}$.

Pierwszymi Polakami, którzy pojawili się na obszarze Mandżurii, byli jeńcy wojenni z drugiej połowy XVII wieku. Rosjanie utworzyli z nich oddziały wojsko-

działalność na początku lat dwudziestych XX wieku od wystawienia Dziadów Adama Mickiewicza oraz Kordiana Juliusza Słowackiego. Do połowy lat trzydziestych XX wieku zaprezentowano publiczności w Harbinie m.in. Hajduczka na motywach powieści Henryka Sienkiewicza (1923), Pana Geldhaba Aleksandra Fredry (1924), fragmenty Wesela Stanisława Wyspiańskiego (1930), Pana Beneta A. Fredry (1930), a także Uciekta mi przepióreczka Stefana Żeromskiego w 1933 r. (M. KAŁusKI, Polacy w Chinach, Warszawa 2001, s. 133).

${ }^{14}$ Sport był niezwykle istotnym elementem życia harbińskiej Polonii. Od końca lat dwudziestych XX wieku zakładano różne drużyny sportowe, które były wspierane nie tylko przez „Gospodę Polską", lecz także przez polskie Gimnazjum im. Henryka Sienkiewicza (Zakład Narodowy im. Ossolińskich, Czasopisma, sygn. 292.827, Dwa mecze polskie, „Listy Harbińskie” 1932, nr 11, s. 8). Walenty Kuczyński, jeden z czternastu przyszłych ochotników do walki w Wojsku Polskim i jednocześnie absolwent gimnazjum, po ukończeniu Centralnego Instytutu Wychowania Fizycznego w Warszawie wrócił do Harbina (tuż przed napaścią III Rzeszy na Polskę) i został nauczycielem wychowania fizycznego w gimnazjum. Dzięki staraniom jemu podobnych nauczycieli uprawiano koszykówkę, siatkówkę i żeglarstwo. Szczególnie silna była gimnazjalna drużyna hokeja na lodzie, która pokonała nawet japońską reprezentację olimpijską (M. Katuski, Polacy w Chinach, s. 155).

${ }^{15}$ I. Mitrofanov, The Lands and Land Administration of the Chinese Eastern Railway Company. And the Incident of August 1st, 1923, Harbin 1923, s. 5; E. Batson PricE, The Russo-Japanese Treaties of 1907-1916 Concerning Manchuria and Mongolia, Baltimore 1933, s. 124.

16 Podstawą do jej budowy była umowa zawarta między Imperium Rosyjskim a Cesarstwem Chin 8 września 1896 r. (J.V.A. MacMurray, Treaties and Agreements with and Concerning China, 1894-1919, tom 1, New York 1921, s. 270).

${ }^{17}$ AAN, KPM, sygn. 66, Historia kolonii polskiej w Mandżurii, opracował Kazimierz Krąkowski, k. 7.

${ }^{18}$ K.W. Chan, Misconceptions and Complexities in the Study of China's Cities. Definitions, Statistics, and Implications, „Eurasian Geography and Economics” 48(2007), nr 4, s. 383-402.

19 AAG, APP, sygn. 50, Raport Konsulatu Generalnego w Sydney z 18 października 1933 r., k. $70-75$. 
we, które kilkakrotnie wkroczyły na obszary leżące po południowej stronie rzeki Amur $^{20}$. W większej liczbie Polacy pojawili się na tych terenach także po upadku Powstania Styczniowego. Jednak dopiero dobrowolne przyjazdy przyczyniły się do zapoczątkowania dostrzegalnego, a z czasem uporządkowanego, skupiska Polaków. W krótkim czasie Polakom, korzystającym ze sprzyjających warunków politycznych ${ }^{21}$ i odpowiedniego przygotowania zawodowego, udało się zając eksponowane stanowiska w lokalnej gospodarce. Dodatkowo część naszych rodaków doskonale odnalazła się w bankowości, handlu, medycynie, sądownictwie, a nawet samorządzie miejskim ${ }^{22}$. Autorem pierwszego planu miasta był inż. Konstanty Jokisz, zaś w 1908 r. zastępcą burmistrza został inż. Eugeniusz Dynowski, który w latach 1910-1911 pełnił funkcję burmistrza. W tym samym czasie Rada Miejska Harbina była całkowicie zdominowana przez Polaków i Niemców ${ }^{23}$.

W mieście działało również polskie szkolnictwo stopnia powszechnego i średniego $^{24}$, a przy nim dwie drużyny harcerskie ${ }^{25}$. Dzieci i młodzież nauczano według

${ }^{20}$ A. Aleksandrowicz, Mandżuria, jej przeszłość, teraźniejszość, kraj i ludzie, Warszawa 1937, s. 107.

${ }^{21}$ Porażka Rosjan w wojnie z Japonią (1904-1905), wybuch I wojny światowej (1914) i upadek caratu w Rosji w 1917 r. przyniosły Polakom dużą swobodę działania oraz ożywienie mandżurskiej Polonii w pracy narodowej i politycznej (M. KaŁuski, Polska - Chiny 1246-1996, Warszawa 2004, s. 131).

${ }^{22}$ W. TheISs, Dzieci syberyjskie. Dzieje polskich dzieci repatriowanych z Syberii i Mandżurii w latach 1919-1923, Warszawa 1992, s. 28.

${ }^{23}$ K. Grochowski, Polacy na Dalekim Wschodzie, Harbin 1928, s. 55; „Biuletyn Polskiej Izby Handlowej w Harbinie” 1932, nr 5, s. 3; „Listy Harbińskie” 1932, nr 5, s. 2.

${ }^{24} \mathrm{Na}$ początku lat trzydziestych XX wieku w Harbinie polskie szkoły miały około 300 wychowanków. Jednak ogólną liczbę polskich dzieci w wieku szkolnym w Mandżurii szacowano wówczas na 800 osób. Większość z nich nie uczyła się języka polskiego, a tym bardziej nie uczęszczała do polskich placówek oświatowych, przeważnie wybierając naukę w szkołach z wykładowym językiem rosyjskim (IPMS, ARP, sygn. A.44.122/4, List ks. Aleksandra Eysymontta do kierownika Referatu Dalekiego Wschodu w Ministerstwie Spraw Zagranicznych w Warszawie dra Grabowieckiego, Harbin 8 marca 1930 r., k. 207-209).

${ }^{25}$ Początki polskiego ruchu harcerskiego w Harbinie wiążą się z osobami Feliksa Anioła i ppłk. Wacława Jędrzejewicza. Pierwszy z nich założył Stowarzyszenie Gimnastyczne „Sokół” w 1917 r., które wkrótce przekształciło się w Drużynę Harcerską im. Henryka Sienkiewicza. W latach dwudziestych XX wieku w związku z repatriacją do kraju polskie harcerstwo uległo znacznemu osłabieniu. Jednak w 1925 r. sprawnej reorganizacji harcerstwa w Harbinie dokonał Wacław Jędrzejewicz, udający się do Tokio w celu objęcia funkcji attaché wojskowego. Połączył on dwie drużyny męskie w jedną, a następnie odtworzył patronat przedstawicieli parafii, gimnazjum i „Gospody Polskiej”. Odtąd harcerstwo polskie w Mandżurii, przeżywając kolejne okresy chwilowych wzlotów, działało aż do końca polskiej enklawy. W 1937 r. hufiec liczył 35 druhów. Z grona harbińskich harcerzy, których wychowywano w duchu głębokiego patriotyzmu, wywodzili się przyszli wielokrotnie odznaczani żołnierze Samodzielnej Brygady Strzelców Karpackich, w tym Stanisław Dróżdż i Antoni Kajdewicz. 


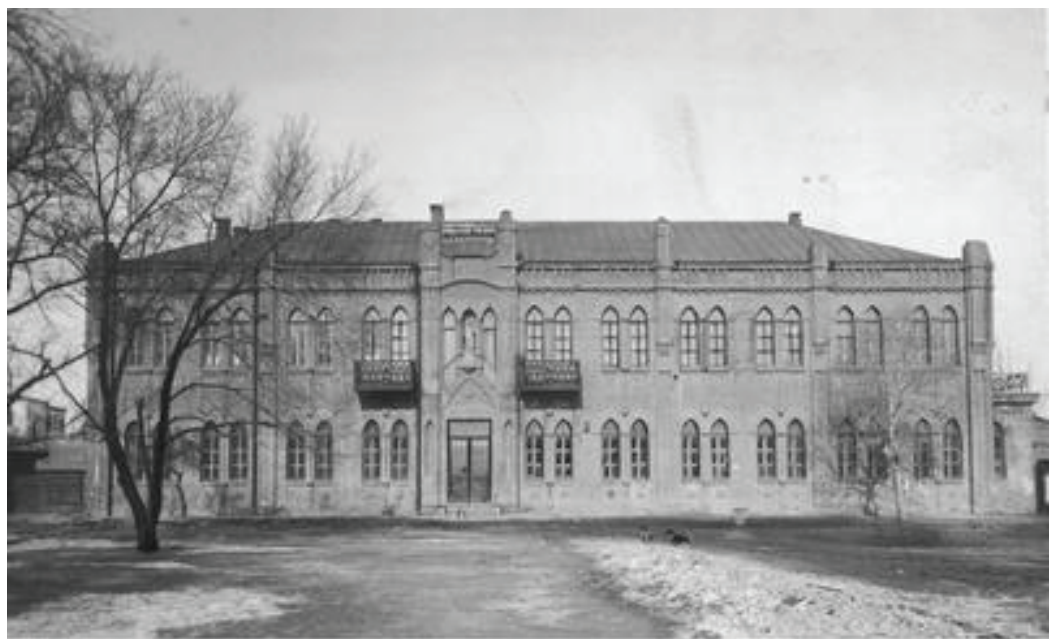

Fot. 1. Gmach Gimnazjum im. Henryka Sienkiewicza w Harbinie (1934)

Źródło: Narodowe Archiwum Cyfrowe, sygn. 1-Z-311.

programów szkolnych obowiązujących w kraju, za zgodą polskiego Ministerstwa Wyznań Religijnych i Oświecenia Publicznego częściowo dostosowanych do realiów dalekowschodnich ${ }^{26}$, co uwidoczniło się w nauce języka chińskiego i japońskiego, historii oraz elementów kultury państw Dalekiego Wschodu ${ }^{27}$. Świadectwa dojrzałości otrzymywane w Gimnazjum im. Henryka Sienkiewicza ${ }^{28}$ w Harbinie

Zwłaszcza ostatni z nich odznaczał się umiejętnością opieki nad najmłodszymi zuchami w Mandżurii („Sybirak” 1937, nr 1, s. 32-33; R.K. DASZKIEwICZ, Harcerstwo polskie poza granicami kraju od zarania do 1930 roku w relacjach i dokumentach, Lublin 1983, s. 173-180; M. KAŁUsKI, Polacy w Chinach, s. 158).

${ }^{26}$ Utrzymanie polskiego szkolnictwa w Mandżurii, jak i pracujących w nim nauczycieli, było możliwe wyłącznie dzięki wsparciu finansowemu płynącemu z polskiego Ministerstwa Wyznań Religijnych i Oświecenia Publicznego za pośrednictwem konsulatu RP w Harbinie. Tym samym polskie instytucje państwowe miały decydujący wpływ na dobór tamtejszej kadry nauczycielskiej (AAN, MSZ, sygn. 11739, Raport administracyjny Delegacji RP w Harbinie za 1928 rok, k. 35).

27 AAN, MSZ, sygn. 10618, Pismo Konsulatu RP w Harbinie z 17 IV 1932 r. w sprawie reorganizacji szkolnictwa, k. 25.

${ }^{28}$ W 1908 r. przy „Gospodzie Polskiej” zaczęła funkcjonować szkoła z językiem wykładowym polskim. Cztery lata później powstała druga szkoła, działająca w pomieszczeniach plebanii. Szkoła przyjęła program jednoklasowych szkół kolejowych, naukę prowadzono w języku rosyjskim. W 1916 r. wprowadzono język polski jako wykładowy. W tym samym roku przekształcono dwa najstarsze roczniki szkoły początkowej w najniższe oddziały gimnazjum im. Henryka Sienkiewicza (Gimnazjum Polskie im. H. Sienkiewicza i Szkoła Poczatkowa im św. Wincentego à Paulo w Charbinie, Chiny, „Pamiętnik Charbiński” 1923, cz 1, s. 42). Proces dydaktyczno-wychowawczy w har- 
uprawniały tamtejszych maturzystów do wstępu na wyższe uczelnie w Polsce, z czego, pomimo trudności finansowych i ofert podjęcia studiów w południowych Chinach, korzystało co roku przynajmniej kilka osób ${ }^{29}$.

Kolejnym ważnym środowiskiem szerzenia kultury oraz myśli patriotycznej wśród Polaków w Mandżurii była prasa polska. Spośród ponad dwudziestu tytułów czasopism, które wydawano w Harbinie, szczególną rolę odegrały wydawnictwa takie, jak „Tygodnik Polski” (1922-1942) „30 „Listy Harbińskie” (1931-1933), „Listy Polskie z Dalekiego Wschodu” (1917-1919) ${ }^{31}$ oraz „Przegląd” (1919-1921) Zwłaszcza „Tygodnik Polski” drukowany przez ponad 20 lat, odegrał pozytywną rolę w życiu Polaków w Harbinie i całej Mandżurii. Jego funkcja kulturotwórcza była jednak znacznie mniejsza od roli, jaką odegrał w życiu społecznym lub religijnym polskiej kolonii. Pismo nie tyle tworzyło kulturę polską, ile ją popierało. W podobny sposób wspierało oświatę polską i działalność patriotyczną Polonii.

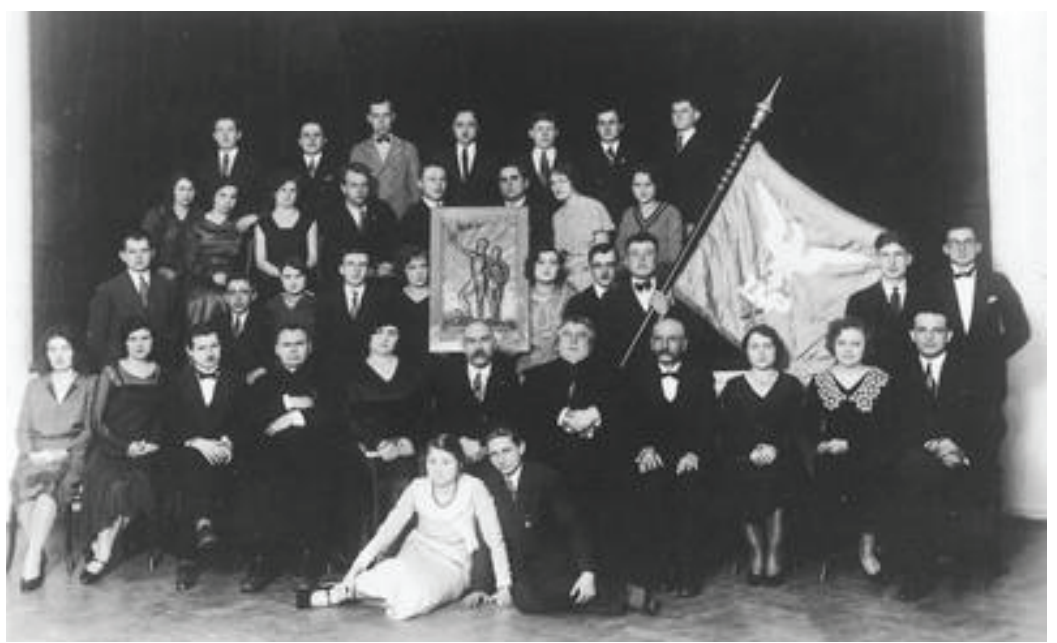

Fot. 2. Członkowie i działacze Związku Młodzieży Polskiej w Harbinie (1931) Źródło: Narodowe Archiwum Cyfrowe, sygn. 1-Z-309-2.

bińskim gimnazjum był nastawiony na patriotyczne wychowanie młodzieży. Stąd szczególną uwagę zwracano na nauczanie języka polskiego, historii i geografii Polski, a także religii. Rozwijano też działalność drużyn harcerskich i organizacji uczniowskich, m.in. kółek samopomocy koleżeńskiej (M. KlimczaK, Polska szkoła średnia w Harbinie - Gimnazjum im. Henryka Sienkiewicza (19151949), [w:] Polskie ślady na Dalekim Wschodzie, s. 172-173).

${ }_{29}$ Co robić po ukończeniu gimnazjum w Harbinie?, „Listy Harbińskie” 1932, nr 12, s. 1.

30 J. ŁoJEK, Historia prasy polskiej. Prasa polska 1918-1939, t. II, Warszawa 1980, s. 401.

31 Prasa polska na Dalekim Wschodzie, „Daleki Wschód” 1934, nr 7, s. 10; K. WoźNIAKowski, Polonia chińska w latach 1897-1949, „Przegląd Polonijny” 1976, z. 1, s. 100-103.

32 K.Y. Deog, Kolonia polska w Mandżurii 1897-1949, Kraków 2001, s. 85-88. 
Na łamach „Tygodnika Polskiego” ukazywały się liczne informacje o życiu codziennym w Polsce ${ }^{33}$, przy czym szczególnie dużo miejsca poświęcano na relacjonowanie wydarzeń związanych z obchodami świąt państwowych, na przykład Świętem Morza ${ }^{34}$.

Wspomniane wcześniej instytucje oraz wydawnictwa pełniły rolę żywego ogniska słowa i kultury polskiej w Mandżurii, mającego decydujący wpływ na bohaterską postawę przedstawicieli tutejszej Polonii, którzy zdecydowali się wstąpić w szeregi Polskich Sił Zbrojnych na Zachodzie. Początkowo w Harbinie istniało liczne i szybko rozrastające się grono Polaków. Niestety, podanie dokładnej liczby naszych rodaków w północno-wschodnich Chinach nie jest możliwe ${ }^{35}$. Liczebność polskiej społeczności szacowano w różnym czasie na 10 tys. osób w samym Harbinie i 20 tys. w całej Mandżurii ${ }^{36}$. Liczba ta mogła być nawet nieznacznie większa, gdyż rewolucja i wojna domowa w Rosji spowodowały napływ wielu tysięcy Polaków z Syberii do północnych Chin. Większość z nich była tam tylko przejazdem, jednak zaowocowało to ożywieniem polskiej działalności narodowej w Harbinie.

Tuż po wojnie rosyjsko-japońskiej z lat 1904-1905 kolonia polska w Harbinie składała się z przynajmniej 3 tys. osób ${ }^{37}$. Jednocześnie już w 1907 r. Polonia mandżurska liczyła 7 tys. przedstawicieli ${ }^{38}$. Co więcej, w okresie od 1917 do 1920 r. na terenie Harbina przebywało aż 14 tys. naszych rodaków ${ }^{39}$, a łącznie nie mniej niż 20 tys. na obszarze Mandżurii ${ }^{40}$. W kolejnej dekadzie mandżurskie miasta zalała fala rosyjskich uchodźców, uciekających przed bolszewikami. W tym samym czasie, według oficjalnych danych polskiego Ministerstwa Spraw Zagranicznych, na obszarze całych Chin znajdowało się około 5 tys. Polaków ${ }^{41}$, w tym blisko 3 tys. w Harbinie ${ }^{42}$. Dla porównania - ówczesną liczbę Japończyków, którzy w 1932 r.

33 AAG, APP, sygn. 65, fragmenty „Tygodnika Polskiego” z 19 grudnia 1926 r. (nr 246), k. 16.

34 „Tygodnik Polski” 1933, nr 576, s. 1.

${ }^{35}$ Liczba Polaków w Harbinie i okolicy ulegała ciągłym zmianom z uwagi na powroty do kraju ojczystego bądź też wyjazdy do innych regionów Chin (J. MisIUReK, Z dziejów duszpasterstwa polonijnego w Harbinie (1901-1925), „Studia Polonijne” 1(1976), s. 190.

${ }^{36}$ E. KAJDAŃsKi, Chiny - Leksykon. Historia, gospodarka, kultura, Warszawa 2005, s. 87.

37 Elenchus cleri et ecclesiarum archidioeceseos Mohiloviensis, Varsovia 1912, s. 68.

38 AAN, MSZ, sygn. 10389, Polacy w Chinach i ZSRR - na Dalekim Wschodzie, k. 5.

39 B.А. Анучин, Географические очерки Маньчжурии, Москва 1948, s. 39; А. JABŁoŃsKA, K. Krąkowski, Z dziejów Polonii Harbińskiej, s. 160-162.

40 В.П. ПЕтров, Город на Сунгари, Вашингтон 1984, s. 8-10.

${ }^{41}$ AAG, APP, sygn. 65, fragmenty „Tygodnika Polskiego” z 19 grudnia 1926 r. (nr 246), k. 17; A. Stawarz, Polacy na Wschodzie XVIII-XX wiek, Warszawa 1998, s. 171.

${ }^{42}$ Wychodźstwo polskie w poszczególnych krajach. Materiaty opracowane na podstawie sprawozdań konsularnych przez referat emigracyjny w Wydziale Administracyjno-Paszportowym Departamentu Konsularnego MSZ (kwiecień 1926), Warszawa 1926, s. 47. 
zdominowali miasto i cały region, oceniano na blisko 4 tys. osób ${ }^{43}$. Jednak z biegiem lat liczba polskich osadników w Mandżurii stale się zmniejszała. W $1930 \mathrm{r}$. w Harbinie mieszkało już tylko niecałe 2 tys. Polaków ${ }^{44}$. Podobne informacje na łamach czasopisma „Echo z Dalekiego Wschodu” zamieścił, będący na miejscu, prezes Polskiej Izby Handlowej Wiktor Radwan, który był przekonany, iż w samym Harbinie znajdowało się około 1,5 tys. Polaków, zaś w całej Mandżurii nie mniej niż 3 tys. reprezentantów polskiej diaspory ${ }^{45}$. Wraz z pogarszającą się sytuacją materialną Polonii jej liczebność utrzymywała się na niskim poziomie. Większość naszych rodaków opuściła niewielkie miejscowości na terenie Mandżurii i przeniosła się do Harbina. Stąd w latach 1935-1949 wielkość polskiego skupiska w Mandżurii, a więc głównie Harbinie, szacowano na przynajmniej 1,250 osób, chociaż liczba ta mogła być nieco zaniżona ${ }^{46}$.

To głównie spośród harcerzy i absolwentów Gimnazjum im. Henryka Sienkiewicza wywodzili się chińscy Polacy, którzy w listopadzie 1939 r. zgłosili się do służby w Wojsku Polskim. Jednak w okresie międzywojennym młodzi Polacy z Mandżurii i Chin byli oficjalnie zwolnieni z obowiązku służby wojskowej ${ }^{47}$. Pomimo tego wielu harbińczyków wyjeżdżało do Polski na studia oraz w celu wstąpienia do armii. We wrześniu 1939 r. co najmniej piętnastu młodych przedstawicieli harbińskiej diaspory przebywało w Polsce na studiach, bądź też w szeregach wojska ${ }^{48}$. Losy większości z nich podczas II wojny światowej nie są dokładnie rozpoznane, ale łączy je kilka wspólnych cech. Chociaż urodzili się w różnych miejscowościach na terenie Mandżurii, to wszyscy byli wychowankami Gimnazjum im. Henryka Sienkiewicza w Harbinie, gdzie oprócz nauki wpajano im wartości patriotyczne. Stamtąd, po zdaniu matury, wyjechali do Polski w drugiej połowie lat trzydziestych XX wieku. Najczęściej studiowali w Warszawie, Krakowie i Wilnie ${ }^{49}$.

Jednym z nich był Andrzej Grochowski ${ }^{50}$, który w 1938 r., dzięki zdaniu wszystkich egzaminów, został przyjęty na Akademię Górniczą w Krakowie, po czym

${ }^{43}$ „Listy Harbińskie” 1932, nr 1, s. 6.

${ }^{44}$ AAN, Konsulat Generalny RP w Charbinie [dalej: KGRP], sygn. 5, Wykaz stanu liczbowego Polaków za granicą z 21 stycznia 1931 r., (brak paginacji).

45 „Echo z Dalekiego Wschodu” 1934, nr 3, s. 17.

46 A. Winiarz, Działalność Polskiego Komitetu Opiekuńczego w Harbinie (1942-1945), „Rocznik Polonijny" 1984-1985, s. 196.

${ }^{47}$ M. Kaluski, Polska - Chiny 1246-1996, s. 134.

${ }^{48}$ M. Kaluski, Polacy w Chinach, s. 177.

49 A. Grochowski, Jeszcze o Polonii mandżurskiej, „Nasza Rodzina” 1984, nr 11(482), s. 32-35.

${ }^{50}$ Andrzej Grochowski, syn Kazimierza Grochowskiego (1873-1937) - zasłużonego działacza Polonii harbińskiej, geologa, badacza Syberii, Mandżurii i Mongolii, redaktora kilku lokalnych gazet, a także dyrektora Gimnazjum im. Henryka Sienkiewicza - urodził się w Harbinie w 1921 r. Był bratem dwa lata młodszego od niego Mariana, który również brał czynny udział w walkach na frontach 


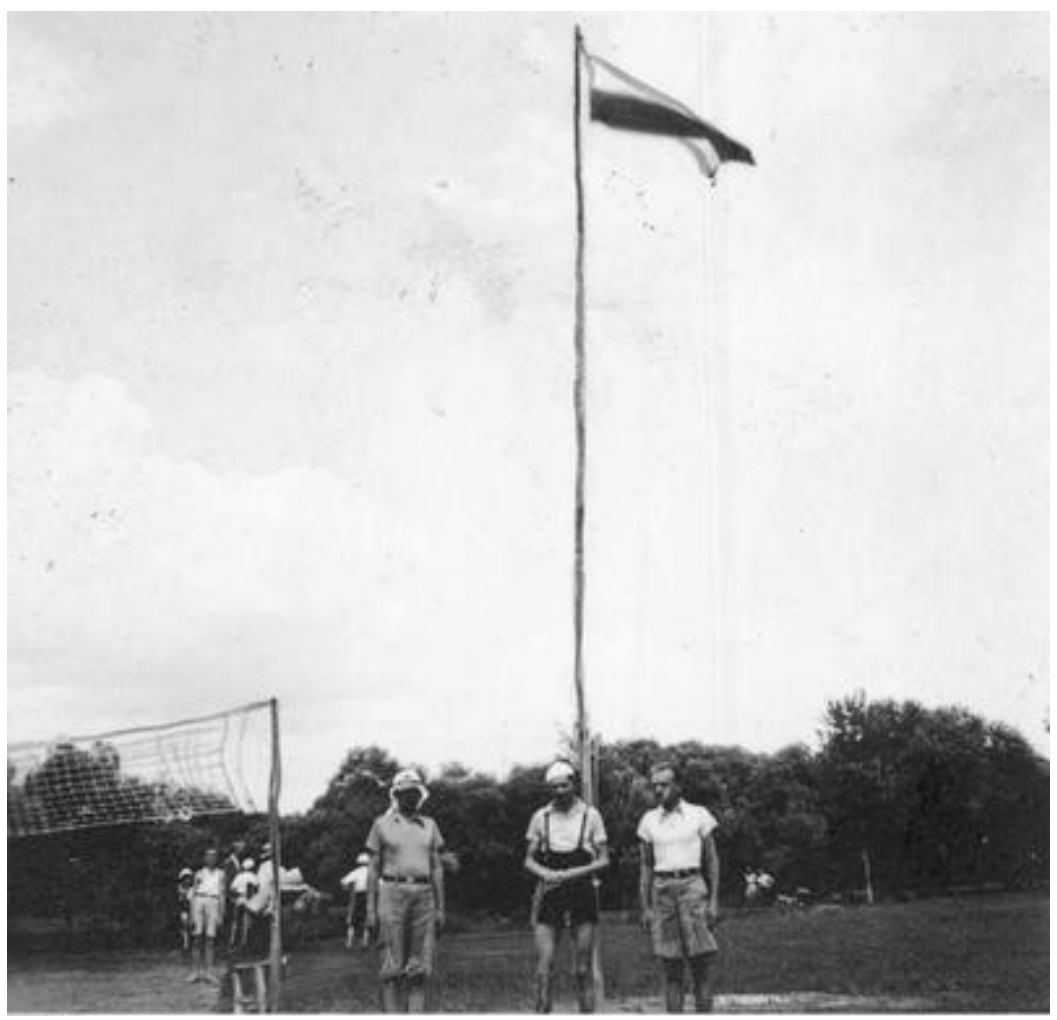

Fot. 3. Komendanci polskiego obozu harcerskiego w Mandżurii (1937) Źródło: Narodowe Archiwum Cyfrowe, sygn. 1-Z-316-1.

wstąpił do krakowskiej Legii Akademickiej, ćwicząc każdego tygodnia w 20. Pułku Piechoty w Łobzowie. Lato 1939 r. spędził u krewnych na Huculszczyźnie w Małopolsce Wschodniej ${ }^{51}$. Kiedy wrócił do Krakowa, w mieście nie było już jego pułku.

II wojny światowej. Droga Mariana Grochowskiego do Polskich Sił Zbrojnych na Zachodzie zaczęła się 30 lipca 1942 r. w Japonii, gdy wraz z personelem polskiej ambasady w Tokio i grupą alianckich dyplomatów został przewieziony z Jokohamy do Mozambiku. Po pewnym czasie wymieniono ich na personel japońskich placówek dyplomatycznych, a następnie przetransportowano do Anglii. Marian otrzymał przydział do 1. Pułku Artylerii Przeciwpancernej w Szkocji. Za walkę pod Falaise, służąc w 1. Dywizji Pancernej gen. Stanisława Maczka, odznaczono go Krzyżem Walecznych, natomiast wojnę zakończył uzyskując stopień oficerski (E. KAJDAŃsKi, Dziennik syberyjskich podróży Kazimierza Grochowskiego 1910-1914, Lublin 1986, s. 25; M. Kaluski, Polacy w Chinach, s. 183).

${ }^{51}$ W XII wieku obszar ten należał do Rusi Halicko-Wołyńskiej, natomiast od czasów Kazimierza Wielkiego (XIV wiek) Huculszczyzna znajdowała się w obrębie Rzeczypospolitej. W 1772 r. w wyniku I rozbioru Polski tereny te weszły w skład monarchii austriackiej, a następnie austro-węgierskiej. $\mathrm{Z}$ kolei w latach międzywojennych region ten ponownie znalazł się w granicach państwa polskiego. Jednak po 1945 r. Huculszczyzna przestała należeć do Polski. Wówczas Polacy wraz z innymi mniej- 
Wówczas opuścił Kraków i przyłączył się do 116. Pułku Piechoty, wchodzącego w skład wojsk Odwodu Naczelnego Wodza, który stacjonował na Lubelszczyźnie. Po całkowitym załamaniu się kampanii wrześniowej przez kilka dni przynależał do oddziału partyzanckiego kpt. Hofmana ${ }^{52}$. Grochowski, podobnie jak inni harbińczycy, postanowił dołączyć do Wojska Polskiego tworzonego na Zachodzie początkowo we Francji, a następnie na terenie Wielkiej Brytanii ${ }^{33}$. Złapany przez żołnierzy Armii Czerwonej na granicy węgierskiej, został zesłany do łagru w głąb Rosji. W następstwie układu Sikorski-Majski z dnia 30 lipca 1941 r. ${ }^{54}$ wstąpił do Wojska Polskiego tworzonego w Związku Sowieckim przez gen. Władysława Andersa, a podległego rządowi w Londynie. W jego szeregach przeszedł cały szlak bojowy, w tym ewakuację do Iranu oraz Iraku, a także walkę we Włoszech, a po zakończeniu wojny, wobec niemożności powrotu ani do Polski, ani do Chin, zamieszkał w Angliii ${ }^{55}$.

Do Polskich Sił Zbrojnych w ZSRR wstąpili także inni Polacy z Mandżurii, którzy uczestniczyli w obronie terytorium Polski przed niemiecką agresją, a następnie dostali się do sowieckiej niewoli i przeżyli zesłanie na Sybir. Był wśród nich również Wiktor Pasternacki ${ }^{56}$. Tuż przed wybuchem II wojny światowej ukończył Szkołę Podchorążych w Grodnie i otrzymał przydział do pułku w Lidzie. Po rozbiciu pułku przez Niemców przedostał się do Warszawy, gdzie brał udział w walkach obronnych i został ranny. Jednak uniknął niewoli niemieckiej i uciekł do Białegostoku, aby dostać się na Litwę, gdzie mieszkali jego dalecy krewni ${ }^{57}$. Natomiast tam dostał się w ręce Rosjan. Natychmiast przewieziono go do Moskwy, uznano za szpiega i skazano na dziesięć lat w łagrach na dalekiej Północy. Wiktor Pasternacki został zwolniony w 1941 r., następnie wstąpił do tworzonego

szościami narodowymi zostali stamtąd wypędzeni (T. Figlus, Past and present of Hutsulshchyna as the Carpathian borderland region. Remarks on changes of spatial structures, ethno-cultural specificity and heritage, [w:] Historical Regions Divided by the Borders, red. M. Sobczyński, K. Heffner, Łódź 2009, s. 143-157).

${ }^{52}$ M. Kaluski, Polska - Chiny 1246-1996, s. 135.

53 W. Biegański, Polskie Siły Zbrojne na Zachodzie, Warszawa 1990, s. 21.

${ }^{54}$ J. ŚlusarCZYK, Układ polsko-radziecki z 30.7.1941 r., „Wojskowy Przegląd Historyczny” 1981, nr 3, s. 5.

${ }_{55}$ M. Cabanowski, Tajemnice Mandżurii. Polacy w Harbinie, Warszawa 1993, s. 94.

${ }^{56}$ Co ciekawe, po ukończeniu Gimnazjum im. Henryka Sienkiewicza w Harbinie przeprowadził się do Szanghaju, gdzie założył dobrze prosperujący garaż i warsztat reparacji samochodów. Jednak jego pragnieniem było ukończenie studiów w Polsce. W tym celu zlikwidował swoje przedsiębiorstwo i przeniósł się do Polski, aby odbyć służbę wojskową przed podjęciem studiów (A. KosıŃsKA, Udziat Polonii harbińskiej w drugiej wojnie światowej, [w:] Chiny w oczach Polaków. Księga jubileuszowa z okazji 60-lecia nawiązania stosunków dyplomatycznych między Polska a Chińska Republikg Ludowa, Gdańsk 2010, s. 126).

${ }^{57}$ M. Kaluski, Polacy w Chinach, s. 179. 
wojska polskiego w Rosji. W Palestynie oraz Iraku, jako świetny mechanik, szkolił innych żołnierzy. Z kolei na włoskim froncie dowodził czołówkami warsztatowymi w 3. Dywizji Strzelców Karpackich ${ }^{58}$.

Podobnie potoczyły się losy Piotra Sudnika, który zaraz po zdaniu matury w polskim gimnazjum w Harbinie opuścił Mandżurię. Już w Polsce wstąpił do szkoły podchorążych. Brał również udział w wojnie obronnej z 1939 r., a pod jej koniec dostał się do niewoli radzieckiej ${ }^{59}$. W konsekwencji został zesłany na Sybir do gułagu, skąd na mocy porozumienia Sikorski-Majski zaciągnął się do powstającego pod dowództwem gen. Władysława Andersa Wojska Polskiego. Następnie uczestniczył w kampanii włoskiej, a także w walkach na terenie Europy. Za bohaterstwo okazane pod Monte Cassino został odznaczony krzyżem Virtuti Militari, zaś wojnę zakończył ze stopniem oficerskim ${ }^{60}$.

Witold Józef Świderski, także absolwent Gimnazjum im. Henryka Sienkiewicza w Harbinie, ukończył w Polsce studia prawnicze w Warszawie oraz Szkołę Podchorążych Kawalerii w Grudziądzu, uzyskując stopień podporucznika. Zmobilizowany 3 września 1939 r. został dowódcą plutonu w 23. Pułku Ułanów Grodzieńskich. Walczył pod Augustowem, a później został przerzucony wraz z pułkiem na Wołyń pod Sarny, gdzie dowodzeni przez niego żołnierze rozbili dużą bandę Ukraińców współpracujących z Sowietami, ratując otoczoną grupę wojskowych, wśród których znajdował się m.in. gen. Bronisław Regulski. W kolejnych dniach walczył z wojskami rosyjskimi pod Stochodem. Pod koniec września otrzymał rozkaz kapitulacji. We wrześniu 1940 r. został aresztowany w Nowej Wilejce przez władze radzieckie i zesłany na Syberię do Workuty. Tam podzieli los innych zwolnionych na podstawie porozumienia Sikorski-Majski w $1941 \mathrm{r}^{61}{ }^{61}$ Wówczas wstąpił do tworzonej przez gen. Andersa armii polskiej w Rosji. Szlak bojowy przeszedł w szeregach 12. Pułku Ułanów Podolskich w kampanii włoskiej. Najbardziej odznaczył się w walkach pod Piedimonte i nad rzeką Sangro, za co został awansowany do stopnia porucznika i odznaczony krzyżem Virtuti Militari ${ }^{62}$.

Jednak nie wszystkim harbińczykom udało się przyłączyć do Polskich Sił Zbrojnych na Zachodzie. Romuald Świderski, brat Witolda Józefa, urodzony 10 grudnia 1914 r. w niewielkiej miejscowości Suifenho na pograniczu rosyjsko-mandżurskim ${ }^{63}$,

${ }^{58}$ M. Cabanowski, Tajemnice Mandżurii, s. 96.

${ }^{59}$ M. Kaluski, Polska - Chiny 1246-1996, s. 136.

${ }^{60}$ Książnica Pomorska, Zbiory specjalne, sygn. 3402, Andrzej Grochowski, Niedomknięte koła, „Tydzień Polski - Londyn”, k. 16.

${ }^{61}$ A. KosińsKa, Udziat Polonii harbińskiej w drugiej wojnie światowej, s. 127.

${ }^{62}$ M. Kaluski, Polacy w Chinach, s. 178.

${ }^{63}$ Obecnie Suifenhe to stutysięczne miasto powiatowe w południowo-wschodniej części prowincji Heilongjiang, w Chińskiej Republice Ludowej. Znajduje się w miejscu, z którego tory dawnej 
po ukończeniu polskiego gimnazjum w Harbinie pojechał do Polski na studia i przeszkolenie w szkole podchorążych. Dzięki temu został porucznikiem w wileńskim 5. Pułku Piechoty Legionów. We wrześniu 1939 r. został ciężko ranny w rękę pod Serockiem. Uciekł ze szpitala i potem działał w podziemiu, walcząc bohaterstwo w Powstaniu Warszawskim (1944), za co został odznaczony krzyżem Virtuti Militari i Krzyżem Armii Krajowej ${ }^{64}$.

Biografie dwóch następnych przedstawicieli Polonii harbińskiej są znane tylko w niewielkim stopniu. Pierwszym z nich jest porucznik Michał Franciszek Paciorek, o którym wiadomo, że jako zastępca oficera operacyjnego Wołyńskiej Brygady Kawalerii walczył z Niemcami pod Tomaszowem Lubelskim prawdopodobnie do 27 września 1939 r. Właśnie jemu przypadła najdłuższa wędrówka do 2. Korpusu gen. Władysława Andersa ${ }^{65}$, którą odbył wraz z bratem, podporucznikiem Zbigniewem Paciorkiem ${ }^{66}$. Po kampanii wrześniowej obydwaj przekroczyli granicę polsko-litewską, a następnie staraniami osobistymi uzyskali wizę japońską. $Z$ zachodu na wschód przemierzyli Związek Sowiecki, dotarli do Japonii, stamtąd odwrotnie do Port Saidu. Rotmistrz Zbigniew Paciorek poległ pod Monte Cassino, zaś major i zastępca dowódcy Pułku Ułanów Karpackich Michał Paciorek zginął w północnych Włoszech w 1945 r. w następstwie wypadku samochodowego ${ }^{67}$.

Przedstawione w ogólnym zarysie losy przedstawicieli Polonii mandżurskiej, którzy w momencie agresji Niemiec hitlerowskich i Związku Sowieckiego na Polskę we wrześniu 1939 r. znajdowali się na terytorium II Rzeczypospolitej, a wcześniej przebywali w miejscu oddalonym o 10 tysięcy kilometrów od swojej ojczyzny, wskazują na szczere zaangażowanie i odwagę wykazane przez nich w walce o niepodległą Polskę. Zachowanie Polaków wywodzących się z Mandżurii i Chin podczas II wojny światowej uwidacznia ponadto fakt, że prowadzona tam działalność oświatowo-wychowawcza nie była pozbawiona sensu i przyniosła wymierne efekty. Stąd też uprzednio wpajane im wartości patriotyczne oraz konieczność podtrzymywania więzów z krajem ojczystym nie zostały przez nich ani zaprzepaszczone, ani bezpowrotnie zapomniane.

\footnotetext{
Kolei Wschodniochińskiej prowadzą do rosyjskiego Kraju Nadmorskiego. Suifenhe wraz z otaczającymi je obszarami pogranicznymi było miejscem zaciętych walk, gdy Związek Sowiecki zaatakował terytorium marionetkowego państwa Mandżukuo w sierpniu 1945 r. (E.M. STOLBERG, Stalin und die chinesischen Kommunisten 1945-1953. Eine Studie zur Entstehungsgeschichte der sowjetisch-chinesischen Allianz vor dem Hintergrund des Kalten Krieges, Stuttgart 1997, s. 102; M. MeYer, In Manchuria. A Village Called Wasteland and the Transformation of Rural China, New York 2015, s. 112).

${ }^{64}$ M. Kaluski, Polska - Chiny 1246-1996, s. 135.

65 A. Majewski, Zaczęło się w Tobruku, Lublin 1973, s. 349.

${ }^{66}$ A. Popiel, Korpus Kadetów Nr 1: 1918-1939, Katowice 2003, s. 140.

${ }^{67}$ P. WiкTorski, Na koniec wzeszło stońce, Warszawa 1985, s. 157.
} 


\section{BIBLIOGRAFIA}

\section{Źródla archiwalne}

Archiwum Akt Nowych w Warszawie

Kolonia Polska w Mandżurii

Konsulat Generalny RP w Charbinie

Ministerstwo Spraw Zagranicznych

Archiwum Archidiecezjalne w Gnieźnie

Archiwum Prymasa Polski

Archiwum Towarzystwa Chrystusowego w Poznaniu

Liber baptizatorum 1906-1909

Centralne Archiwum Wojskowe w Warszawie

Oddział II Sztabu Głównego (Generalnego) z lat 1921-1939

Instytut Józefa Piłsudskiego w Ameryce (Nowy Jork)

Adiutantura Generalna Naczelnego Wodza

Instytut Polski i Muzeum im. gen. Sikorskiego w Londynie

Ambasada RP przy Stolicy Apostolskiej

Książnica Pomorska w Szczecinie

Zbiory specjalne

Narodowe Archiwum Cyfrowe w Warszawie

Zakład Narodowy im. Ossolińskich we Wrocławiu

Czasopisma

Zbiory prywatne Leonarda Spychalskiego

\section{Opracowania}

AleKSANDrowicz A., Mandżuria, jej przeszłość, teraźniejszość, kraj i ludzie, Warszawa: Biblioteka Polska 1937.

Анучин В.А., Географические очерки Маньчжурии, Москва: Государственное издатеьство географической литературы 1948.

Batson Price E., The Russo-Japanese Treaties of 1907-1916 Concerning Manchuria and Mongolia, Baltimore: Johns Hopkins Press 1933.

Biegański W., Polskie Siły Zbrojne na Zachodzie, Warszawa: Krajowa Agencja Wydawnicza 1990.

Cabanowski M., Tajemnice Mandżurii. Polacy w Harbinie, Warszawa: Muzeum Niepodległości 1993.

DASzKIEWICZ R.K., Harcerstwo polskie poza granicami kraju od zarania do 1930 roku w relacjach i dokumentach, Lublin: Katolicki Uniwersytet Lubelski 1983.

DeOG K.Y., Kolonia polska w Mandżurii 1897-1949, Kraków: PROMO 2001.

Elenchus cleri et ecclesiarum archidioeceseos Mohiloviensis, Varsovia: Vincentii Kluczyński 1912. 
Figlus T., Past and present of Hutsulshchyna as the Carpathian borderland region. Remarks on changes of spatial structures, ethno-cultural specificity and heritage, [w:] Historical Regions Divided by the Borders, red. M. Sobczyński, K. Heffner, Łódź: Uniwersytet Łódzki 2009.

Grochowski K., Polacy na Dalekim Wschodzie, Harbin: Harbin Daily News Press 1928.

JudycKa A., Judycki Z., Duchowieństwo polskie w świecie, Toruń: Oficyna Wydawnicza Kucharski 2002.

KAJDAŃsKi E., Chiny - Leksykon. Historia, gospodarka, kultura, Warszawa: Książka i Wiedza 2005.

KAJDAŃSKI E., Dziennik syberyjskich podróży Kazimierza Grochowskiego 1910-1914, Lublin: Wydawnictwo Lubelskie 1986.

KAJDAŃSKi E., Korytarz. Burzliwe dzieje Kolei Wschodniochińskiej 1898-1998, Warszawa: Książka i Wiedza 2000.

KaŁuski M., Polacy w Chinach, Warszawa: Instytut Wydawniczy Pax 2001.

KAŁuski M., Polska - Chiny 1246-1996, Warszawa: Verbinum 2004.

KLimczaK M., Polska szkoła średnia w Harbinie - Gimnazjum im. Henryka Sienkiewicza (1915-1949), [w:] Polskie ślady na Dalekim Wschodzie. Polacy w Harbinie, red. A. Furier, Szczecin: Książnica Pomorska im. Stanisława Staszica 2008.

KosińsKa A., Udział Polonii harbińskiej w drugiej wojnie światowej, [w:] Chiny w oczach Polaków. Księga jubileuszowa z okazji 60-lecia nawiązania stosunków dyplomatycznych między Polską a Chińską Republiką Ludową, Gdańsk: Wydawnictwo Uniwersytetu Gdańskiego 2010.

ŁoJEK J., Historia prasy polskiej. Prasa polska 1918-1939, t. II, Warszawa: PWN 1980.

MacMurray J.V.A., Treaties and Agreements with and Concerning China, 1894-1919, t. I, New York: Oxford University Press 1921.

MAJEwsKi A., Zaczęło się w Tobruku, Lublin: Wydawnictwo Lubelskie 1973.

Meyer M., In Manchuria. A Village Called Wasteland and the Transformation of Rural China, New York: Bloomsbury Press 2015.

Mitrofanov I., The Lands and Land Administration of the Chinese Eastern Railway Company. And the Incident of August 1st, 1923, Harbin: Chinese Eastern Railway 1923.

Петров В.П., Город на Сунгари, Вашингтон: Изд. Русско-американского исторического общества 1984.

Polska Służba Zagraniczna po 1 września 1939 roku, Londyn: Wydawnictwo SPPSZ 1954.

PopIEL A., Korpus Kadetów Nr 1: 1918-1939, Katowice: Wydawnictwo Naukowe „Śląsk” 2003.

SKóRA W., Organizacja i pierwszy okres działalności polskich konsulatów w Harbinie i Władywostoku w latach 1920-1924, [w:] Polskie ślady na Dalekim Wschodzie. Polacy w Harbinie, red. A. Furier, Szczecin: Książnica Pomorska im. Stanisława Staszica 2008.

SKóRA W., Placówki MSZ Drugiej Rzeczypospolitej w Harbinie w latach 1920-1941 na tle dziejów Chin i Mandżurii (Mandżukuo). Szkic do problemu, [w:] Na szlakach dwóch światów. Studia ofiarowane Profesorowi Jerzemu Hauzińskiemu w 45-lecie pracy naukowej i dydaktycznej, red. A. Teterycz-Puzio, Słupsk: Akademia Pomorska 2016. 
SKÓRA W., Służba konsularna Drugiej Rzeczypospolitej. Organizacja, kadry i działalność, Toruń: Wydawnictwo Adam Marszałek 2006.

SŁawiŃski R., The Modern History of China, Kraków: Księgarnia Akademicka 2006.

Stawarz A., Polacy na Wschodzie XVIII-XX wiek, Warszawa: Muzeum Niepodległości 1998.

Stolberg E.M., Stalin und die chinesischen Kommunisten 1945-1953. Eine Studie zur Entstehungsgeschichte der sowjetisch-chinesischen Allianz vor dem Hintergrund des Kalten Krieges, Stuttgart: Franz Steiner 1997.

Symonolewicz K., Miraże mandżurskie, Warszawa: Gebethner i Wolff 1932.

THEIsS W., Dzieci syberyjskie. Dzieje polskich dzieci repatriowanych z Syberii i Mandżurii w latach 1919-1923, Warszawa: Uniwersytet Warszawski 1992.

TYcZKa J., Na wschodzie i na zachodzie, Warszawa: Verbinum 2003.

WiKTORsкi P., Na koniec wzeszło słońce, Warszawa: Wydawnictwo Ministerstwa Obrony Narodowej 1985.

WojCIECHOwicz M., Placówka wschodnia w Harbinie, [w:] Marianie 1673-1973, red. J. Bukowicz, T. Górski, Rzym: MIC 1975.

Wychodźstwo polskie w poszczególnych krajach. Materiały opracowane na podstawie sprawozdań konsularnych przez referat emigracyjny w Wydziale Administracyjno-Paszportowym Departamentu Konsularnego MSZ (kwiecień 1926), Warszawa: Ministerstwo Spraw Zagranicznych 1926.

\section{Czasopisma}

„Biuletyn Polskiej Izby Handlowej w Harbinie” 1932, nr 5.

Chan K.W., Misconceptions and Complexities in the Study of China's Cities. Definitions, Statistics, and Implications, „Eurasian Geography and Economics”, 48(2007), nr 4.

Co robić po ukończeniu gimnazjum w Harbinie?, „Listy Harbińskie” 1932, nr 12.

CZERmiŃski M., Z opowiadań Władysława Ostrowskiego, „Misje Katolickie” 1912, nr 31.

„Daleki Wschód” 1934, nr 7.

„Echo z Dalekiego Wschodu” 1934, nr 3.

Gimnazjum Polskie im. H. Sienkiewicza i Szkoła Początkowa im. św. Wincentego à Paulo w Charbinie, Chiny, „Pamiętnik Charbiński” 1923, cz. 1.

Grochowski A., Jeszcze o Polonii mandżurskiej, „Nasza Rodzina” 1984, nr 11(482).

Historia parafii polsko-katolickiej w Charbinie, „Pamiętnik Charbiński” 1923, cz. 1.

JabŁoŃSKa A., KrąKOwski K., Z dziejów Polonii Harbińskiej, „Przegląd Orientalistyczny” 1961, nr 2(38).

„Listy Harbińskie” 1932, nr 1.

„Listy Harbińskie” 1932, nr 5.

MisiureK J., Z dziejów duszpasterstwa polonijnego w Harbinie (1901-1925), „Studia Polonijne" 1(1976).

Neja J., Polacy w Mandżurii, „Biuletyn Instytutu Pamięci Narodowej” 2002, nr 3.

NerNHeJM S., Polonia harbińska (zarys historyczny), „Daleki Wschód” 1934, nr 7.

„Praca. Pismo Postępowe i Demokratyczne” 1918, nr 8. 
Prasa polska na Dalekim Wschodzie, „Daleki Wschód” 1934, nr 7.

Polski list z Dalekiego Wschodu, „Dziennik Łódzki” 1931, nr 87.

Polsko-chińska misja ss. urszulanek, „Gazeta Polska” 1933, nr 37.

SejBuK C., Polskie Siostry Urszulanki w Harbinie, „Misje Katolickie” 1938, nr 57.

Stowarzyszenia polskie w Charbinie, Chiny, „Pamiętnik Charbiński” 1923, cz. 1.

„Sybirak” 1937, nr 1.

Symonolewicz-Symmons K., Polonia w Charbinie, „Przegląd Polonijny” 1978, z. 2.

ŚLuSARCZYK J., Układ polsko-radziecki z 30.7.1941 r., „Wojskowy Przegląd Historyczny” 1981, nr 3.

ŚwiDERSKI M., Uwaga kolejarze, „Listy Harbińskie” 1932, nr 14.

„Tygodnik Polski” 1933, nr 576.

WinIarz A., Działalność Polskiego Komitetu Opiekuńczego w Harbinie (1942-1945),

„Rocznik Polonijny” 1984-1985.

WoJas B.Z., Dzieje Polonii Charbińskiej, „Zeszyty Historyczne” (Paryż) 30(1974).

WoźNiakowski K., Polonia chińska w latach 1897-1949, „Przegląd Polonijny” 1976, z. 1.

\author{
Z DALEKIEGO WSCHODU NA BLISKI WSCHÓD, \\ DO AFRYKI PÓŁNOCNEJ I EUROPY. \\ POLACY Z MANDŻURII W SZEREGACH WOJSKA POLSKIEGO \\ W LATACH 1939-1945
}

Streszczenie

Historia Polaków wywodzących się z Mandżurii, którzy brali udział w kampanii wrześniowej, a także w walkach Samodzielnej Brygady Strzelców Karpackich, jak i innych jednostek Polskich Sił Zbrojnych na Zachodzie, to nie tylko niezwykle chlubna karta dziejów Polonii mandżurskiej, lecz również oręża polskiego oraz narodu polskiego walczącego o swoje przetrwanie w szczególnie ciężkich warunkach II wojny światowej. Bohaterska postawa wielu Polaków z Mandżurii walczących w Wojsku Polskim jest tym bardziej godna uwagi, że część z nich znała Polskę wyłącznie z opowiadań swoich rodziców bądź nauczycieli, mimo to po jej upadku w 1939 r. byli oni gotowi do walki o jej wyzwolenie.

Słowa kluczowe: Polonia; Mandżuria; Wojsko Polskie 


\section{FROM THE FAR EAST TO THE MIDDLE EAST, NORTH AFRICA AND EUROPE. POLES FROM MANCHURIA IN THE RANKS OF THE POLISH ARMED FORCES, 1939-1945 \\ Sum mary}

The history of Poles originating from Manchuria who participated in the 1939 Defensive War, and in the combat operations of the Independent Carpathian Rifle Brigade, as well as other units of the Polish Armed Forces in the West, is not only a glorious card in the history of Polish diaspora in Manchuria, but it also marks strength of the Polish Army and a nation which was forced to fight for its survival in particularly difficult conditions of World War II. The heroic attitude of many Poles from Manchuria fighting in the Polish Army is all the more remarkable that some of them knew Poland only from the stories told them by their parents or teachers, however after its fall in 1939 they were ready to fight for its liberation.

Key words: Polish Diaspora; Manchuria; Polish Armed Forces 